\title{
A review of the effect of medicinal plant on helminthic infections
}

\author{
Faham Khamesipour, ${ }^{1}$ Parya Kheyri, ${ }^{1,2}$ Shadan Shojaat, ${ }^{1}$ Bahareh Chelgerdi Dehkordi, ${ }^{1}$ \\ Bahareh Basirpour, ${ }^{3}$ Sana Sadat Afzal, ${ }^{1}$ Sakineh Akbari, ${ }^{3}$ Seyed Hossein Hejazi ${ }^{3,4}$ \\ ${ }^{1}$ Shahrekord Branch, Islamic Azad University, Shahrekord; ${ }^{2}$ Young Researchers and Elite Club; \\ ${ }^{3}$ Department of Parasitology and Mycology; ${ }^{4}$ Skin Diseases and Leishmaniasis Research Center, \\ Department of Parasitology and Mycology, School of Medicine, Isfahan University of Medical Sciences, \\ Isfahan, Iran
}

\begin{abstract}
Nowadays, parasitic worm infection is one of the most critical global health problems. Worm infections cause severe detriments to the livestock industry and also it can cause irreparable damages to immunocompromised persons. Therefore, the present study aimed to review conducted research on the treatment of worm diseases using medicinal plants' extract. In this systematic review, seven databases including 4 English (Scopus, PubMed, ScienceDirect, Google Scholar) and 3 Persian databases (Magiran, ISC, SID) were obtained between 2008 and 2020 to evaluate conducted studies related to the aim of the current review. Most of the
\end{abstract}

Correspondence: Parya Kheyri, Faculty of Veterinary Medicine, Shahrekord Branch, Islamic Azad University, Shahrekord, Iran, P.O. Box 166.

E-mail: kheyriiparya@gmail.com

Keywords: Anti-worm; herbal medicinal; review.

Acknowledgments: The authors would like to thank Mr. Saeed Nezaratizadeh, for his support and guidance throughout the study. Also, we are appreciative of Cheraghipour et al., "The Effect of Medicinal Plant Extracts on Helminthes: A Systematic Review" for using its translation in our article.

Contributions: All authors discussed the results and contributed to the final manuscript.

Conflict of interest: The authors declare no conflict of interest.

Availability of data and materials: All data generated or analyzed during this study are included in this published article.

Ethics approval and consent to participate: Not applicable.

Informed consent: Not applicable.

Received for publication: 30 November 2020.

Revision received: 25 March 2021

Accepted for publication: 10 April 2021.

This work is licensed under a Creative Commons Attribution NonCommercial 4.0 License (CC BY-NC 4.0).

${ }^{\circ}$ Copyright: the Author(s),2021

Licensee PAGEPress, Italy

Infectious Diseases and Herbal Medicine 2021: 2:127

doi:10.4081/idhm.2021.127 studies focused on the Balanites aegyptiaca and Carica papaya plant. Water was the most common solvent (38.1\%) and then it was methanol. The most studied parasite was Haemonchus contortus (35.5\%), followed by Aacharidia galli (10.5\%). Studies showed that plant extracts could reduce effect of worm infections in the host compared to synthetic drugs. Plant extracts can produce a medicine based on natural compounds and effective on worms with fewer side effects than synthetic drugs.

\section{Introduction}

One of the most critical health problems is parasitic worm infection that negatively affects third-world countries' social, health, and economic conditions. ${ }^{1}$ Serious detriments have caused worm infections to the livestock industry with symptoms such as weight loss, decreased milk, meat, and wool production. Most importantly, these infections can also cause irreparable damages to immunocompromised individuals..$^{2-4}$ Today, various anthelmintics used to control worm infections have significant benefits in reducing worm load. However, these medicines' efficiency has been decreased due to medicinal resistance. ${ }^{3-4}$ Because of the continuous use of anthelmintic. Interest in medicinal plants or their compounds in modern research against worm infection is increasing due to inaccessible and expensive synthetic drugs. Traditional medicines can be used as effective anti-worm treatment in many human and livestock populations because of easy access and appropriate effect. Within this framework, medicinal plants and herbal derivatives have been used as anti-worm treatments over the years by people. ${ }^{4,5}$ The appropriate anthelmintic should have an available range and clinical therapeutic ability, including being taken as a single dose, no toxicity in the host, and low cost. Currently, none of the synthetic drugs have such properties. Side effects of synthetic drugs include nausea, digestive disorders, and dizziness. ${ }^{6}$ According to the World Health Organization, $60 \%$ of developing countries still do not have anthelmintic medicines. ${ }^{7}$ In developing countries, people still depend on different herbal remedies to treat worm infections, and herbal medicines and traditional treatments are the sources of health care to treat various diseases such as intestinal worm infection in these areas. ${ }^{7}$ Thus, herbal remedies can provide an alternative to synthetic anthelmintic drugs and have fewer side effects and more efficacy than synthetic drugs; this indicates medicinal plant-based products to treat patients infected with worm infections. ${ }^{8}$ Due to the increasing trend of patients with immunodeficiency worldwide, it seems necessary to screen them for infection with Strongyloides stercoralis and produce new medicines to treat such patients. ${ }^{9}$ Several studies on worm models such as Phertima posthuma, ${ }^{10}$ Ascaridia galli ${ }^{11}$ due to physiological and anatomical resemblance with human intestin- 
al nematodes and treatment with medicinal plants have been done. Therefore, it seems necessary to use medicinal plants in the prevention and emergence of new therapeutic approaches due to worm infection treatment. The present study aimed to investigate the research conducted to treat worm disease using medicinal plant extracts.

\section{Material and Methods}

\section{Searching databases}

In this study, search for resources in 7 databases including 4 English databases (Scopus, PubMed, Science Direct, Google scholar) And 3 Persian databases (scientific information database or SID, Magiran, and ISC) through the years of 2018 - 2020 and in Persian and English, to review the studies about the purpose of the present study. The combination of the words "Herbal medicine," "Extract," "In vitro," "In vivo," and "Parasitic helminths" were used to search.

\section{Review and entry of studies}

Studies in which the effect of a plant extract or its derivatives on one or more parasitic worms was measured were selected. First, analyses were recorded in Mendeley software version 7, and duplicate tasks were eliminated. Two independent authors then reviewed abstracts, and related articles were selected. The same two authors carefully read the selected studies, and the cases that met the inclusion criteria were added to the survey. Other studies were excluded from the study due to deficiencies in the required information, lack of access to the full text, non-compliance of methods with the results, and misinterpretation of the products. How studies were selected is shown in Figure 1.

\section{Data extraction and analysis}

Two independent authors extracted the required information from the selected articles and, if necessary, the difference between the two was resolved by the other author.

\section{Results}

Out of 3431articles selected in the searching phase, 76 of them were eligible for inclusion in the study. The results of this review study showed that most studies were focused on Balanites aegypti$a c a$ and Carica papaya. Water (38.1\%) and then Methanol (36.8\%) were the most used solvents in extraction. Heamonchus contortus (35.5\%) and then Aacharidia galli (10.5\%) were the most studied parasites. The extracted information is given in Table 1.

\section{Discussion}

Recently, special attention has been paid to modern therapies using herbs to treat various diseases like parasitic infections. Numerous studies have been performed on anthelmintic and antiprotozoal effects of different plant extracts in vitro and in vivo conditions. ${ }^{12-15}$ The present study examines the constant use of herbs, searching for new herbs, and their further production and effects and mechanisms of various extracts of herbs to replace with standard synthetic drugs.

\section{Using herbs is a treatment for Haemonchus contortus}

A gastrointestinal parasite that causes Haemonchosis disease. This parasite is found in the abomasum of goats and sheep. Economic losses resulting from Haemonchosis in tropical and subtropical areas often cause mortality and a reduction in livestock production and growth. ${ }^{16}$ A study by Sambodo et al. showed that the crude aqueous extract of Biophytum petersianum has proper anathematic properties against Haemonchus contortus. In this study, a $10 \%$ concentration of this plant's aqueous extract in the 24 hours caused $100 \%$ death of worms. Also, in reviews using a scanning electron microscope (SEM), changes in the structure of worms like cuticle destruction, cervical protrusions loss, anterior part destruction, and posterior part shrinkage of the parasite in the $10 \%$ concentration of the aqueous extract of this plant were observed. ${ }^{17}$ Von Son - de Fernex et al. showed antiparasitic properties of the tropical plants Cratylia argentea, C. argentea veran$d a$, Arachis pintoi, Gliricidia sepium, and Yacapani against Haemonchus contortus. In this study, a concentration of 1,200 $\mu \mathrm{g} / \mathrm{mL}$ of these plants' extract inhibited the molting and migration process of Haemonchus contortus larvae. ${ }^{18}$ Also, effects of the aqueous extract of Annona leaf was studied against Haemonchus contortus in eggs, larvae, and adult stages in vitro environment that showed a high concentration of $A$. muricata extract affected Egg Hatching Test (EHT) and larval motility assay test (LMT) by $84.91 \%$ and $89.08 \%$, respectively, which was related to Phenolic compounds in the plant. ${ }^{19}$ A study of Castaneda Ramirez et al. examined Acacia pennatula vessels' role in Larval Escheatment Inhibition Assay test (LEILA). In this study, it was found that the less the age of the larval stage of Haemonchus contortus (L3) is, the less concentration of Acacia pennatula extract is required to inhibit escheatment; so $100 \mu \mathrm{g} / \mathrm{mL}$ in the first week and 200 $\mu \mathrm{g} / \mathrm{mL}$ in the fifth week were efficient. ${ }^{20}$ Using Piper tuberculatum and Hura crepitans extracts at EHT $=9$ affected Larval Development test (LD). Lippia sidoides had the best effect on EHT and LDT stage in inhibiting Haemonchus contortus larva growth. ${ }^{21}$

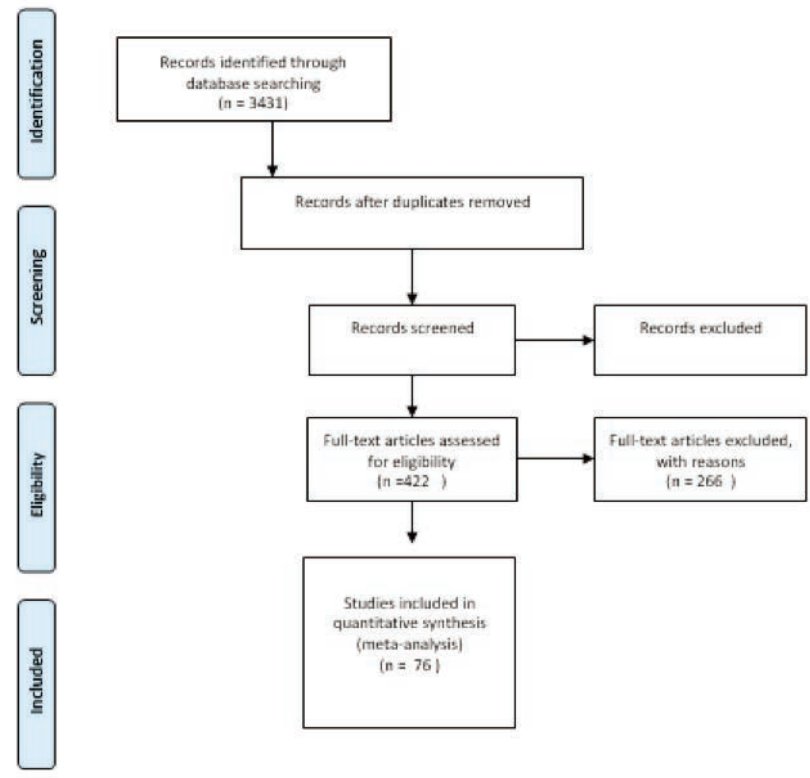

Figure 1. Flow chart of selection of relevant publications 
Table 1. Extracted data from studies.

\begin{tabular}{|c|c|c|c|c|c|}
\hline Plant name & Solvent & Parasite name & In vivo /in vitro & Results & Reference \\
\hline $\begin{array}{l}\text { Azadirachta indica (A.Juss.) } \\
\text { Annona squamosal(neem) } \\
\text { Tobacco (Nicotiana tabacum) }\end{array}$ & water & Nematodes in goats & Invivo & $\begin{array}{l}\text { Revealed no reductions on day } \\
10 \text { post-infection in animals treated } \\
\text { with herbal extracts. }\end{array}$ & {$[60]$} \\
\hline Mysine Africana (kechemo) & Hydroalcoholic & Hookworm & $\begin{array}{l}\text { Invitro } \\
\text { In vivo }\end{array}$ & $\begin{array}{l}\text { 80\% of Hydraalcoholic extracts of } \\
\text { M. Africans exhibited larricidal activity. } \\
\text { The LC50 was 217.77 microgram per milliliter } \\
\text { The lethal dose (LD50) of the plant extract } \\
\text { was beyond 2000mg grg of body weight. }\end{array}$ & {$[61]$} \\
\hline Mitragyna inermis (willd.) Kuntze & Powder of leaves & Haemonchus contortus & Invivo & $\begin{array}{l}\text { The powder of M. Inermis leaves ( }>60 \%) \\
\text { significantly reduced }(p<0.01) \text { fecal egg } \\
\text { counts in the three breeds of lambs. }\end{array}$ & {$[62]$} \\
\hline Maytenus emarginata(willd.)Ding Hou & $\begin{array}{l}\text { methanol } \\
\text { water } \\
\text { hydroalcohol }\end{array}$ & $\begin{array}{l}\text { Pheretima posthuma } \\
\text { Ascaridia galli. }\end{array}$ & In vitro & $\begin{array}{l}\text { Peak activity } \\
\text { Was exhibited by the methanolic extract } \\
\text { at a concentration of } 50 \mathrm{mg} / \mathrm{mL} \text {. }\end{array}$ & {$[63]$} \\
\hline $\begin{array}{l}\text { Ferula asafoetida (H.Karst.) } \\
\text { Allium sativum L. }\end{array}$ & hydroalcoholic & Strongylus spp. & Invitro & $\begin{array}{l}\text { Hydroalcoholic extract of F.asafoetida at } \\
\text { a concentration of 10,50, and } 100 \mathrm{mg} / \mathrm{mL} \\
\text { killed over } 90 \% \text { of the larvae, and A. Sativum } \\
\text { extract at the concentration of } 50 \text { and } \\
100 \mathrm{mg} / \mathrm{mL} \text { killed over } 95 \% \text { of larvae( }(\mathrm{p}<0.05) \text {. }\end{array}$ & [64] \\
\hline Carica papaya L. & $\begin{array}{l}\text { water } \\
\text { ethyl } \\
\text { acetate }\end{array}$ & $\begin{array}{l}\text { Pheritima posthuma } \\
\text { Petroleum ether }\end{array}$ & In vitro & $\begin{array}{l}\text { Aqueous extract gave the highest extractive yield } \\
\text { of 19.8\%, followed by the ethyl acetate extract at 17.2\%. }\end{array}$ & {$[65]$} \\
\hline Saba Senegalensis (A.DC.) pichon & $\begin{array}{l}\text { aqueous decoction (AD) } \\
\text { hydroethanolic macerate(HEM) }\end{array}$ & Heligmosomoides bakeri & Invitro & $\begin{array}{l}\text { HEN's ovicidal and larvicidal activity is more } \\
\text { interesting than that of } \mathrm{AD} \text { with an Emax }=95.60 \% \\
\text { and an I } \mathrm{C}_{50}=390 \text { ygg ML. }\end{array}$ & {$[66]$} \\
\hline Gigantochloa apus (Schult.) Kurz & water & Haemonchus contortus & In vitro & $\begin{array}{l}\text { The crude aqueous extract, looks more pointed. } \\
\text { Morphometry study of } h \text {. Contortus indicates that it has } \\
\text { a significant difference for body length, body width, } \\
\text { cervical papillae, and spicule length in the male. }\end{array}$ & [67] \\
\hline Cymbopogon citratus (DC.) Stapf & $\begin{array}{l}\text { water } \\
\text { methanol }\end{array}$ & $\begin{array}{l}\text { Haemonchus spp. } \\
\text { Trichostrongylus spp. }\end{array}$ & Invitro & $\begin{array}{l}\text { Both extracts were active against Haemonchus spp. } \\
\text { And Trichostrongylus spp. Larvae. }\end{array}$ & [68] \\
\hline Saponins from Medicago spp. & Methanol & Strongilus & Invitro & $\begin{array}{l}\text { With } 1.72 \mathrm{mg} / \mathrm{mL} \text { EC50 and } 3.84 \mathrm{mg} / \mathrm{mL} \text { EC90, } \\
\text { a saponin from M. Polymorpha cultivars Anglona } \\
\text { was the most active. }\end{array}$ & [69] \\
\hline ginger (Z. officinale) & ethanol & Protoscolices of hydatid cyst & Invitro & $\begin{array}{l}\text { There was no significant difference between } \\
\text { the three concentrations of 200, } 150 \text {, and } 100 \mathrm{mg} / \mathrm{mL} \text { ( } \mathrm{P}>0.05) \text {. }\end{array}$ & {$[70]$} \\
\hline schleichera oleosa (Louri:) & $\begin{array}{l}\text { ether } \\
\text { water } \\
\text { ethanol } \\
\text { chloroform } \\
\text { acetone }\end{array}$ & $\begin{array}{l}\text { Eisenia fetida } \\
\text { Excauates } \\
\text { Perionyx } \\
\text { Pheretima } \\
\text { Posthuma } \\
\text { Ascaridia galli }\end{array}$ & Invitro & $\begin{array}{l}\text { Significant anthelmintic activity was established by the } \\
\text { ethanolic and aqueous extracts. Inhibition of alpha-amylase } \\
\text { by ethanolic and aqueous extracts was significant with } \\
\text { the IC I value of } 36.63 \text { and } 73.94 \mu \mathrm{\mu g} \text { mL, respectively, } \\
\text { compared to standard acarbose. }\end{array}$ & [71] \\
\hline Areca catechu $L$. & water & Ascaridia galli & Both & $\begin{array}{l}\text { The extract damaged the morphology of } A \text {. Galli in vitro. } \\
\text { The average eggs per gram decreased from } 1485 \pm 386.62 \text { to } 0 \pm 0.00 \\
\text { during } 14 \text { days of treatment of } 79 \mathrm{mg} / \mathrm{mL} \text { of extract in vivo. }\end{array}$ & [72] \\
\hline Balanites aegyptiaca (L) Delile & methanol & Toxocara canis & Invitro & $\begin{array}{l}\text { The main changes induced by treatment with the tested extract } \\
\text { were wrinkled cuticular surface and deformed sensory papillae. }\end{array}$ & 73] \\
\hline $\begin{array}{l}\text { Albizia gummifera (J.FGmel.) C.A.Sm. } \\
\text { Phytolacca dodecandra LHér: } \\
\text { Vernonia amygdalina Del. }\end{array}$ & hydroalcoholic & Ovine GIT nematodes & Invitro & $\begin{array}{l}\text { All three plant crude extracts were inhibited egg hatchability significantly } \\
(p<0.05) \text { as compared with the negative control but the inhibition } \\
\text { among them was not significantly different in the effect. }\end{array}$ & [74] \\
\hline Cassia spp. & $\begin{array}{l}\text { n-hexane } \\
\text { ethanol }\end{array}$ & Heemonchus contortus & In vitro & $\begin{array}{l}\text { The movement of H. Contortus larvae was significantly inhibited atter } \\
\text { exposure to Among the species of Cassia, the C. Surattensis (at } 200 \mathrm{mg} / \mathrm{mL} \\
\text { showed the highest }(p<0.05) \text { inhibition level on the larvae. }\end{array}$ & [75] \\
\hline Camellia sinensis (L.) Kuntze & Ethanol & Haemonchus contortus & Invitro & $\begin{array}{l}\text { Both A. Lebbeck and C. Sinensis exhibited 88\% and 95\% mortality } \\
\text { at } 6 \& 8 \mathrm{mg} / \mathrm{mL} \text { after } 8 \text { hours of treatment. }\end{array}$ & [76] \\
\hline $\begin{array}{l}\text { Albizia lebbeck (L.) Benth } \\
\text { Bridelia ferruginea Benth } \\
\text { Combretum glutinosum Perr. exDC. } \\
\text { Mitragyna inermis (Willd.) Kuntze }\end{array}$ & $\begin{array}{l}\text { Methanol } \\
\text { acetone }\end{array}$ & Heemonchus contortus & Invitro & $\begin{array}{l}\text { At the highest concentration ( } 2400 \mu \mathrm{\mu g} / \mathrm{mL}) \text {, all adult worms were } \\
\text { motionless after } 24 \text { hof exposure, while at the lowest concentration } \\
(<150 \mu \mathrm{\mu g} / \mathrm{mL}) \text {, this occurred after } 48 \text { hof exposure. M. Inermis and } \\
\text { C. Glutinosum extracts were more effective than B. Ferruginea } \\
\text { extracts }(p<0.05) \text {. }\end{array}$ & [77] \\
\hline Syzygiumaromaticum (clove) & water & Hymenolepisnanain & Invivo & $\begin{array}{l}\text { The extracted oil's lethal and therapeutic doses were also calculated } \\
\text { as } 225 \text { and } 2.25 \mathrm{mg} / \mathrm{kg} \text {. }\end{array}$ & [78] \\
\hline
\end{tabular}


Table 1. Continue from previous page.

\begin{tabular}{|c|c|c|c|c|c|}
\hline Plant name & Solvent & Parasite name & In vivo fin vitro & Results & Reference \\
\hline Syzygiumaromaticum (clove) & water & Hymenolepisnanain & Invivo & $\begin{array}{l}\text { The extracted oil's lethal and therapeutic doses were also calculated } \\
\text { as } 225 \text { and } 2.25 \mathrm{mg} / \mathrm{kg} \text {. }\end{array}$ & [78] \\
\hline Carica papaya & methanol & $\begin{array}{l}\text { Indian earthworms } \\
\text { Cattle worms }\end{array}$ & Invitro & $\begin{array}{l}\text { The result indicated that the Papaya seeds lead to paralysis } \\
\text { of earthworm and death. }\end{array}$ & [79] \\
\hline Jasminum sessiliflorum (Vahl) & $\begin{array}{l}\text { ether } \\
\text { chloroform } \\
\text { ethyl acetate } \\
\text { ethanol }\end{array}$ & $\begin{array}{l}\text { Earthworm } \\
\text { Pheretima posthuma }\end{array}$ & Invitro & $\begin{array}{l}\text { The ethanolic extract was found to produce the highest degree } \\
\text { of positive response. }\end{array}$ & [80] \\
\hline Ocimum sanctum L. & ethanol & Ascaridia galli & In vitro & $\begin{array}{l}\text { The results were LC50 of Ocimum sanctum Linn. Leaves ethanol } \\
\text { extract was 7.9\% at } 4 \text { hours, } 37 \% \text { at } 6 \text { hours, } 1.8 \% \text { at } 8 \text { hours, and } \\
0.8 \% \text { at } 10 \text { hours, and the LC90 was } 8.4 \% \text { at } 10 \text { hours. }\end{array}$ & [81] \\
\hline tobacco (Nicotiana tabacum) & waret & Ascaridia galli & Invitro & $\begin{array}{l}\text { Scanning electron microscopy of tobacco infusion-treated nematodes } \\
\text { showed extensive structural damage. }\end{array}$ & [82] \\
\hline Cymboposon citratus (DC.) Stapf & $\begin{array}{l}\text { essential oils (CCEO) } \\
\text { nanoemulsion } \\
\text { (CCEOn) }\end{array}$ & Haemonchus contortus & $\begin{array}{l}\text { In vivo } \\
\text { In vitro }\end{array}$ & $\begin{array}{l}\text { In the egg hatching test, cceo and cceon (1.25 mo/ml) inhibited larval } \\
\text { hatching by } 98.4 \text { and } 97.1 \% \text {, respectively. Three animals treated with cceo } \\
\text { died whereas in the group treated with cceon one animal died. }\end{array}$ & [83] \\
\hline Hypoestes forskaolii (Vahl) & $\begin{array}{l}\text { n-hexane } \\
\text { methanol } \\
\text { chloroform }\end{array}$ & $\begin{array}{l}\text { Trichostiongylus spp } \\
\text { Chabertia ovina } \\
\text { Cooperia spp } \\
\text { Haemonchus contortus } \\
\text { Teladorsagia spp }\end{array}$ & Invitro & $\begin{array}{l}\text { The n-hexane extract has a percentage of inhibition of egg hatching } \\
\text { greater }(p<0.05) \text { than other extracts inhibiting the 30.8\% at the } \\
\text { concentration of } 1 \mathrm{mg} / \mathrm{mL} \text {. }\end{array}$ & [84] \\
\hline Carica papaya $L$. & hexane & Strongyloides venezulelensis & Invitro & $\begin{array}{l}\text { The extract inhibited egg hatching with high efficiency at concentrations } \\
\text { of } 56.6 \mathrm{mg} / \mathrm{mL} \text { (95.740) and } 5.66 \mathrm{mg} / \mathrm{mL} \text { (92.16\%). }\end{array}$ & {$[85]$} \\
\hline $\begin{array}{l}\text { Artemisia herba-alba Asso } \\
\text { Punica granatum L. }\end{array}$ & methanol & Haemonchus contortus & Invitro & $\begin{array}{l}\text { The highest concentration }(10 \mathrm{mg} / \mathrm{mL}) \text { of all the extracts caused } \\
\text { a significicantly ( } \mathrm{p}<0.05) \text { nematocidal activity. Maximal }(98.67 \% \text { ) egg } \\
\text { hatching inhibition effect was exhibited by the flower extract of } \\
\text { A. Herba-alba at } 1 \mathrm{mg} / \mathrm{mL} \text {. }\end{array}$ & [86] \\
\hline $\begin{array}{l}\text { Lantana camara (L.) } \\
\text { Tamarindus indica } L .\end{array}$ & $\begin{array}{l}\text { methylene chloride } \\
\text { methanol } \\
\text { hexane }\end{array}$ & Onchocerciasis & Invitro & 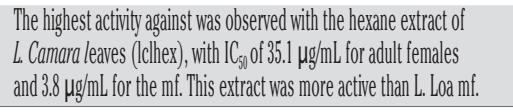 & [87] \\
\hline Terminalia Catappa (Linn) & $\begin{array}{l}\text { ether } \\
\text { ethyl acetate } \\
\text { methanol } \\
\text { Water } \\
\text { Dichloromethane } \\
\text { hydroadcoholic }\end{array}$ & Haemonchus concortus & Invitro & $\begin{array}{l}\text { The dichloromethane extract displayed the highest egg hatch inhibition } \\
\text { percentage of } 98.94 \% \text { at } 6.25 \mathrm{mg} / \mathrm{mL} \text { and also showed } 100 \% \text { larval reduction } \\
\text { at a concentration of } 12.5 \mathrm{mg} / \mathrm{mL} \text { after } 3 \text { days and } 98.9 \% \text { at the least concent } \\
6.25 \mathrm{mg} / \mathrm{mL} \text {. While the methanol extract showed the lowest inhibition of } 95 \text {. } \\
\text { at the same concentration }\end{array}$ & $\begin{array}{l}\text { [88] } \\
\text { intration of } \\
\text { 95.77\% }\end{array}$ \\
\hline Curcuma longa L & $\begin{array}{l}\text { Water } \\
\text { methanol }\end{array}$ & Gastrointestinal nematodes & Invivo & $\begin{array}{l}\text { Revealed ED50 for egg hatch was } 0.594 \text { indicates a high degree } \\
\text { of resistance towards benzimidazole in goats prevaled in the farm. }\end{array}$ & [89] \\
\hline Azadirachta indica(AJuss.) & $\begin{array}{l}\text { chloroform } \\
\text { hexane } \\
\text { ethyl acetate } \\
\text { n-butanol }\end{array}$ & Heemonchus contortus & Invivo & $\begin{array}{l}\text { There was no significant difference statistically (P>0.05) in FECR\% } \\
\text { (45.62 vs 85.14) in sheep at low and high doses of the plant. }\end{array}$ & [90] \\
\hline Ocimum gratissimum L. & acetone & Heemonchus placei & In vivo & $\begin{array}{l}\text { The best-fit LC50 values, found to be significantly different } \\
\text { (apha < } 0.0001 \text { ), were } 17.70 \mathrm{mg} / \mathrm{mL} \text { and } 56.04 \mathrm{mg} / \mathrm{mL} \text { for } \\
\text { C. Citratus and } 0 \text {. Gratissimum, respectively. }\end{array}$ & {$[91]$} \\
\hline Cymbopogon citratus (DC.) Stapf & essential oil (CLEO) & Protoscoleces of hydatid cysts & $\begin{array}{l}\text { Invitro } \\
\text { exvivo }\end{array}$ & $\begin{array}{l}\text { Although CLEO at the doses of } 50 \text {, and } 100 \mu \mathrm{L} / \mathrm{mL} \text { exhibited } \\
\text { no similar effect in the ex vivo analysis; but, at the dose of } 200 \mu \mathrm{L} / \mathrm{mL} \\
\text { and an exposure time of } 5 \text { min, approximately } 100 \% \text { of cysts }\end{array}$ & {$[92]$} \\
\hline $\begin{array}{l}\text { Terminalia bellerica } \\
\text { Terminalia chebula } \\
\text { Terminalia catappa }\end{array}$ & $\begin{array}{l}\text { Hexane } \\
\text { Chloroform } \\
\text { Methanol } \\
\text { Acetone }\end{array}$ & Setaria cervi & Invitro & $\begin{array}{l}\text { T. Bellerica, t. Chebulla and t. Catappa showed a decline in the motility } \\
\text { of the worms at higher doses of } 5 \text { and } 10 \mathrm{mg} / \mathrm{mL} \text { atter } 4 \mathrm{~h} \text { of incubation, } \\
\text { whereas dec (diethylcarbamazine) worms were active at all the doses } \\
\text { upto } 4 \text { hand further after } 24 \mathrm{~h} \text { followed by mtt reduction assay. }\end{array}$ & [93] \\
\hline Murraya koenigii (L.) Spreng. & $\begin{array}{l}\text { Methanol } \\
\text { n-hexane } \\
\text { chloroform } \\
\text { n-butanol } \\
\text { water }\end{array}$ & Haemonchus contortus & Invitro & $\begin{array}{l}\text { Subfractions (SF), SF 3, and } 11 \text { of the chloroform fraction } \\
\text { showed better ovicidal activity whereas SF 2,67,32, and } 37 \text { showed } \\
\text { the best larvicidal activity. The larvae that were used for testing } \\
\text { the larvicidal activity, were found to be sluggishly motile atter } \\
\text { half an hour of incubation with the extract and were progressively } \\
\text { dead in a dose-dependent manner. }\end{array}$ & [94] \\
\hline Maytenus seneggalensis (Lam.) Exell & water & Heemonchus contootus & Invitro & $\begin{array}{l}\text { For the LMI assays, the aqueous extract of M. Senegalensis } \\
\text { showed a significant }(p<0.05) \text { inhibition of larval migration in a } \\
\text { concentration-dependent manner: The highest concentration used } \\
(2400 \mu \mathrm{gg} . \mathrm{mL}-1) \text { showed a 37.77\% inhibition. }\end{array}$ & [95] \\
\hline
\end{tabular}


Table 1. Continue from previous page.

\begin{tabular}{|c|c|c|c|c|c|}
\hline Plant name & Solvent & Parasite name & In vivo /in vitro & Results & leference \\
\hline $\begin{array}{l}\text { Origanum aciculare (Waldst \& Kit.) Kuntze. } \\
\text { Cinnamomum verum J.Presl } \\
\text { Rosmarinus officinalis L. } \\
\text { Capsicum annuum L. }\end{array}$ & water & Haemonchus contortus & Invitro & $\begin{array}{l}\text { In EHT, LC50 values of HC and oxfendazole were } 498 \text { and } 1.6 \text { ppm, } \\
\text { respectively. In AMA, } 100 \% \text { mortality of H.C Contortus was observed after } 6 \text { hr } \\
\text { of treatment with HC (100 mg mL-1) whereas two positive control groups could } \\
\text { not kill all worms atter this exposurre time. These results indicated the anthelmin } \\
\text { potential of HC. }\end{array}$ & 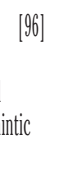 \\
\hline $\begin{array}{l}\text { Dicerocaryum eriocarpum } \\
\text { Pappea capensis } \\
\text { Aloe ferox } \\
\text { Helichrysumsp } \\
\text { Senecio congestus } \\
\text { Senecio barbertonicus } \\
\text { Gardenia sp. }\end{array}$ & water & $\begin{array}{l}\text { Haemonchus } \\
\text { Contortus }\end{array}$ & Invitro & $\begin{array}{l}\text { Larval mortality assays were carried out on the aqueous plant extracts } \\
\text { at concentrations of } 2.5 \mathrm{mg} / \mathrm{mL}, 5 \mathrm{mg} / \mathrm{mL} \text {, and } 7.5 \mathrm{mg} / \mathrm{mL} \text {. } \\
\text { Thiabendazole was used as a positive control. Extracts of all plant species } \\
\text { demonstrated larval mortality abilities that were concentration and time-depende }\end{array}$ & $\begin{array}{l}\text { [97] } \\
\text { dent. }\end{array}$ \\
\hline $\begin{array}{l}\text { ridax procumbens } \\
\text { linn belonging } \\
\text { Asteraceae }\end{array}$ & $\begin{array}{l}\text { chloroform } \\
\text { water }\end{array}$ & Pheritima posthuma & Invitro & $\begin{array}{l}\text { The present study results indicated that the aqueous and chloroform } \\
\text { extracts of leaves of Tridax procumbens linn show significant dose } \\
\text { depending on the pharmacological activity on the Indian earthworms. }\end{array}$ & [98] \\
\hline Embelia schimperi fruits & $\begin{array}{l}\text { n-hexane } \\
\text { Methanol }\end{array}$ & Caenorhabditis elegans & Invitro & $\begin{array}{l}\text { The n-hexane extract exhibited siginificant anthelmintic activity against the [99] } \\
\text { model organism C. Eleganns. The subsequent fractionation procedure } \\
\text { resulted in two active fractions. }\end{array}$ & \\
\hline Dioscorea Mexicana Fruits & Ethanol & Pherithima posthuma & Invivo & $\begin{array}{l}\text { The animal was given a dose of } 0.04 \mathrm{mg} / \mathrm{mL} \text { dose and it was found to be a low } \\
\text { dose which has taken a long time for the paralysis conditions. } \\
0.05 \mathrm{mg} / \mathrm{mL} \text { as the lethal lose and has a perfect time for paralysis } \\
\text { compared to low and high doses. }\end{array}$ & {$[100]$} \\
\hline Zanthoxylum rhetsa & methanol & $\begin{array}{l}\text { Eisenia fetida (Annelida) } \\
\text { Tubifex tubifex (Annelida) }\end{array}$ & Invitro & $\begin{array}{l}\text { The extracts exhibited significant anthelmintic activity as evidenced by a } \\
\text { decrease in paralysis death time in the treatment groups when compared } \\
\text { to standard. }\end{array}$ & {$[101]$} \\
\hline Embelia ribes & Water & Ascaridia galli & Invitro & $\begin{array}{l}\text { Methanolic extract of Embelia ribes showed a better inhibitory effect } \\
(61.23 \%) \text { on the embryo nation of eggs of Ascaridia galli than its aqueous } \\
\text { extract }(58.20 \%) \text {. } \\
\text { Inhibitory effect of } 77.66 \pm 1.85 \% \text {. }\end{array}$ & {$[102]$} \\
\hline $\begin{array}{l}\text { Mangifera indica } \\
\text { Nauclea diderrichii (De Wild.) Merr: }\end{array}$ & $\begin{array}{l}\text { methanol } \\
\text { Chloroform } \\
\text { Acetone } \\
\text { n-hexane }\end{array}$ & Haemonchus placei & Invirto & $\begin{array}{l}\text { The anthelmintic assay shows that acetone extract is worm-active } \\
\text { with a best-fit LC55 of } 16.24 \text { mogmL, while the chloroform extract was inactive. } \\
\text { Fractionation of the acetone extract yielded three fractions (FA, FB, and FC), } \\
\text { Only fraction B was active against H. Placei with LC50 of } 12.24 \mathrm{mg} / \mathrm{mL} \\
\text { of the fractions. }\end{array}$ & {$[103]$} \\
\hline Caesalpinia pulcherrima (Caesalpiniaceae) & $\begin{array}{l}\text { Ether } \\
\text { Dichloro } \\
\text { methane } \\
\text { ethyl acetate } \\
\text { ethanol }\end{array}$ & Eisenia foetida & Invitro & $\begin{array}{l}\text { All the extracts were found to be exhibited dose-dependent } \\
\text { anthelmintic activity. The decreasing order of extracts activity was ethyl acetate, } \\
\text { ethanol, dichloromethane, and petroleum ether extracts. }\end{array}$ & {$[104]$} \\
\hline Citrus aurantiifolia (Christm.) Swingle & ethanol & $\begin{array}{l}\text { Pheritima posthuma } \\
\text { Asha }\end{array}$ & Invitro & $\begin{array}{l}\text { Different concentrations }(2.5,5,10,20 \mathrm{mg} / \mathrm{mL} \text { ) of ethanolic extract of } \\
\text { leaves of Citrus aurantifolia swingle were evaluated for in vitro } \\
\text { anthelmintic activity. The percentage yield of ethanolic extract was obtained } \\
10.5 \text { \& } 7.3 \% \text { w/w respectively. }\end{array}$ & {$[105]$} \\
\hline Carica papaya L & ethanol & $\begin{array}{l}\text { Paramphistomum cervi } \\
\text { Haemonchus contortus }\end{array}$ & Invitro & $\begin{array}{l}\text { Ethanolic extracts of the leaves of the C. Papaya responsible for the } \\
\text { death of P. Cervi and H. Contortus especially at the higher concentration } \\
(100 \%) \text { compared to the standard reference of Piperazine citrate. }\end{array}$ & {$[106]$} \\
\hline cranberry vines(CV) & $\begin{array}{l}\text { Water } \\
\text { organic proanthocyanidin }\end{array}$ & $\begin{array}{l}\text { Haemonch } \\
\text { Us contortus }\end{array}$ & $\begin{array}{l}\text { Invitro } \\
\text { Invivo }\end{array}$ & $\begin{array}{l}\text { CV treated worms were observed via scanning electron microscopy, } \\
\text { and a preliminaryinvestigation of the efficacy of CV powder against } \\
\text { experimental infection of } H \text {. Contortus was conducted. It was determined } \\
\text { by administering } 21.1 \text { g CV powder to lambs for three consecutive days } \\
\text { and collecting fecal legg count data for four weeks post-treatment. } \\
\text { The effect of CV-PAC on egg hatching, L3 motility, and exsheathment was limited }\end{array}$ & [107] \\
\hline Millettia pachycarpa Benth. & methanol & Ascaridia galli & Invitro & The roundworm showed extensive structural changes and damages. & {$[108]$} \\
\hline Biophytum petersianum Klotzsch & water & Haemonchus contortus & Invitro & $\begin{array}{l}\text { Crude aqueous extract of B. Petersianum caused changes in worm structure } \\
\text { such as cuticle destruction, and loss of bumps of the neck. }\end{array}$ & {$[17]$} \\
\hline $\begin{array}{l}\text { Gliricidia } \\
\text { sepium (Jacq.) } \\
\text { Cratyliaargentea Yacapan argentea Veranera }\end{array}$ & water & Haemonchus contortus & Invitro & 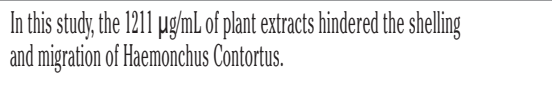 & {$[18]$} \\
\hline $\begin{array}{l}\text { Arachis pintoi C. } \\
\text { Annona muricata L. }\end{array}$ & $\begin{array}{l}\text { acetone } \\
\text { water }\end{array}$ & Haemonchus contortus & Invitro & Annona muricata extract was $84.91 \%$ \%on EHT and 89.08\% on LMT effective. & [19] \\
\hline
\end{tabular}


Table 1. Continue from previous page.

\begin{tabular}{|c|c|c|c|c|c|}
\hline Plant name & Solvent & Parasite name & In vivo /in vitro & Results & Reference \\
\hline Annona muricata $L$. & $\begin{array}{l}\text { water } \\
\text { acetone }\end{array}$ & Haemonchus contortus & Invitro & 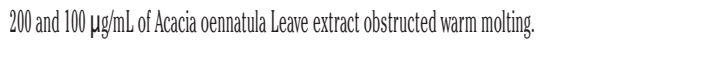 & [20] \\
\hline Piper tuberculatum & Ethyl acetate & Haemonchus contortus & Both & $\begin{array}{l}\text { Lippia sidoides had the best effect on EHT and LDT stages on Haemonchus } \\
\text { contortuth growth. }\end{array}$ & [21] \\
\hline $\begin{array}{l}\text { Hura crepitans } \\
\text { Lippia sidoides Carapa guianensis } \\
\text { Menthe piperita } \\
\text { Leonotis } \\
\text { Occidentalis senna } \\
\text { Leucas martinicensisocymifolia Albizia } \\
\text { Rumex abyssinicus schimperiana }\end{array}$ & $\begin{array}{l}\text { ethanol } \\
\text { Water } \\
\text { Methanol }\end{array}$ & Haemonchus contortus & Invitro & Aqueous extract of Leonotis ocymifolia caused 100\% growth inhibition in larras. & [22] \\
\hline Prunella vulgaris & methanol & Haemonchus contortus & Both & $\begin{array}{l}\text { The most significant decrease in the number of eggs in the feces } \\
\text { was in the group treated with the methanolic extract of Prunella vulgaris. }\end{array}$ & [24] \\
\hline Onobrychis viciifolia & $\begin{array}{l}\text { Acetone } \\
\text { water }\end{array}$ & Haemonchus contortus & Invitro & $\begin{array}{l}\text { Changes such as muscle cell breakdown, intestinal cell lysis, changes in } \\
\text { Hypodermis, and abnormal chromatin density of epithelial cells were observed. } \\
\text { Wounds and lesions also appeared on the surface of the worm. }\end{array}$ & [25] \\
\hline Gliricidia sepium & acetone & Cooperia punctate & Invitro & $\begin{array}{l}\text { After treatment with H-chrome-2-one-2 fractions, In TEM and SEM } \\
\text { examination of eggs of the warm, Changes and fractures in the eggshell of Cooperia } \\
\text { punctate was observed. }\end{array}$ & [27] \\
\hline Leuccena leucocephala & Distilled water & Cooperia punctate & Invitro & $\begin{array}{l}\text { In Treatment with TRIF3 fractions of Leccceena leucocephala, EHT } \\
\text { was 90/49-2885. }\end{array}$ & [28] \\
\hline Chenopodium ambrosioides & $\begin{array}{l}\text { methanol } \\
\text { Diethyl acetate }\end{array}$ & Toxocara canis & Both & $\begin{array}{l}\text { Hexane extracts of Chenopodium ambrosioides reduce Inflammation } \\
\text { in the lungs and liver of Toxocara canis infected mice in vivo and aqueous } \\
\text { extract of Nutridesintox had the best effect in vitro. }\end{array}$ & {$[30]$} \\
\hline Pycnanthus angolensis Nutridesintox & Dichloromethane & $\begin{array}{l}\text { Ancylostoma caninum } \\
\text { hexane }\end{array}$ & Both & $\begin{array}{l}150 \text { ug/mLChenopodium ambrosioides essential oil caused 100\%. } \\
\text { motionless in the larra }\end{array}$ & [32] \\
\hline $\begin{array}{l}\text { Chenopodium ambrosioides L } \\
\text { Vicia pannonica }\end{array}$ & $\begin{array}{l}\text { ethanol } \\
\text { methanol }\end{array}$ & Trichostrongyllu & In vitro & In this study, the Estonian extract caused severe damage to the larva. & [35] \\
\hline $\begin{array}{l}\text { Lysiloma } \\
\text { Pithecellobium Dulce (LAE) accapulcensi }\end{array}$ & Distilled water & $\begin{array}{l}\text { Trichostrogylus } \\
\text { Colbiformis }\end{array}$ & Invitro & $\begin{array}{l}\text { In this studdy, } 250 \mu \mathrm{\mu g} / \mathrm{mL} \text { of LAE reduced warm growth by 32/6\%\%. } \\
\text { The lavicidal ability of Pithecellobium was less than Lysiloma. }\end{array}$ & [36] \\
\hline $\begin{array}{l}\text { Tanshinone II-A (TS II-A) } \\
\text { Cyptotanshinone(CPT) }\end{array}$ & NR & $\begin{array}{l}\text { Angiostrongylus } \\
\text { Cantonensis }\end{array}$ & Invivo & $\begin{array}{l}\text { Combination of Albendazole and Tanshinone II-A reduced neuritis in } \\
\text { Angiostrongylus cantonensis infected mice. }\end{array}$ & [38] \\
\hline Curcumin and ginger & methanol & Ascaridia galli & Both & $\begin{array}{l}\text { Lethal dose } 100 \text { mg/mL of both curcumin and ginger extract was up to } \\
\text { 80\% in48h for Ascaridia galli. }\end{array}$ & {$[11]$} \\
\hline Bolanites aegyptiaca & methanol & Toxocara vitulorum & Invitro & $\begin{array}{l}\text { Treatment with } 120 \mu \mathrm{\mu g} / \mathrm{mL} \text { methanolic extract of BAE made the cuticle } \\
\text { surface wrinkled and the worm surface porous. }\end{array}$ & [43] \\
\hline Balanites aegyptiaca & methanol & Trichinella spiralis & Invivo & $\begin{array}{l}1000 \mathrm{mg} / \mathrm{mL} L \mathrm{~kg} \text { methanolic extract of Balanites aegyptiaca in } 5 \text { days caused } \\
\text { a reduction in warm migration and Larval cysticide in rats. }\end{array}$ & [45] \\
\hline Cynodon dactylon & methanol & Hymenolepis diminuta & Both & $\begin{array}{l}40 \mu \mathrm{\mu g} / \mathrm{mL} \text { of Cynodon dactylon in } 4.12-+0.55 \text { hours caused warm paralysis. } \\
\text { Also in rat treatment with 800mog } \mathrm{mL} / \mathrm{kg} \text { in } 5 \text { days caused a 77/64\%decreas } \\
\text { in the number of eggs in the feces. }\end{array}$ & [47] \\
\hline Alpinia nigra & ethanol & Fasciolopsis buski & Invitro & $\begin{array}{l}20 \mu \mathrm{\mu g} / \mathrm{mL} \text { of ethanolic extract of Alpinia nigra in 2.14-+0.48 hour caused warm } \\
\text { paralysis but in 3.94-23 hour caused death in Fasciola hepatica. }\end{array}$ & [49] \\
\hline $\begin{array}{l}\text { Cajanus cajan } \\
\text { Lantana camara } \\
\text { Bocconia } \\
\text { Piper auritum } \\
\text { Artemisia mexicana } \\
\text { frutescens }\end{array}$ & $\begin{array}{l}\text { Methanol } \\
\text { Ethyl acetate } \\
\text { Hexane }\end{array}$ & Fasciola hepatica & Invitro & $\begin{array}{l}\text { According to this study, the lethal dose of the } 5 \text { studied extracts } \\
\text { Significantly had a lethal effect on the worm. } \\
P<0.05\end{array}$ & [50] \\
\hline Soybean & NR & Fasciola gigantica & Both & $\begin{array}{l}\text { Soybean extract reduced liver damage due to fasciola gigantica and reduced } \\
\text { caspase } 3 \text { in liver cells. }\end{array}$ & [52] \\
\hline Allicin & $\mathbb{N R}$ & Schistosoma mansoni & Invitro & $\begin{array}{l}10 \mu \mathrm{\mu g} / \mathrm{mL} \text { of Allicin caused changes in surface tubercles and spins of the worm. } \\
\text { Upper concentrations caussed severe damages to the worm teggument. }\end{array}$ & [54] \\
\hline Mentha x villosa Huds & Sodium sulfate & Schistosoma mansoni & In vitro & MVEO caused ultra-morphological changes on Schistosoma mansony and tegument distraction. & [55] \\
\hline Clerodendrum umbellatum Poir & water & Schistosoma mansoni & Invivo & Treatment with $160 \mathrm{\mu g} / \mathrm{mL}$ of aqueous Leare extract caused 100\% death in Clerodendrum umbellatum poir: & i. $[56]$ \\
\hline Dregea volubilis & methanol & Paramphistomum microbothrium & Invitro & $\begin{array}{l}100 \text { pg/mL Methanolic extract of Bombax malabaricum in22.17_+.048 minutes caused death in } \\
\text { Paramphistomum explanatum. }\end{array}$ & [58] \\
\hline Balanites aegypticaca & methanol & Paramphistomum microbothrium & Invitro & $\begin{array}{l}200 \mu g / m L \text { Methanolic extract of the fruit of Balanities aegyptiaca Caused severe damages to the } \\
\text { worm tegument. }\end{array}$ & [59] \\
\hline
\end{tabular}


A study of Haemonchus contortus larva EHT and LDT using a hydroalcoholic extract of Senna Occidentalis leaf, the aerial part of Rumex abyssinicus, Leonotis ocymifolia, Albizia schimperiana, and Leucas martinicensis stem bark showed that the aqueous extract of Leonotis Ocymifolia caused 100\% growth of larvae. The best concentration of ED50 for EHT of aqueous and hydroalcoholic extract of Leucas Martinicensis was $0.09 \mathrm{mg} / \mathrm{mL} .^{22}$ In a study, anthelmintic activities of an extract combination of Indica azadirachta leaf, Nicotiana tabacum (N.), Calotropis procera (C.) flower, and Trachyspermum Ammi seed were examined in EHT and Adult Motility Test (AMT) of Haemonchus Contortus worm. Accordingly, by increasing the compound concentration, the amount of EHT decreased. At a concentration of $50 \mathrm{mg} / \mathrm{mL}$, only $1 \%$ of worms hatched; whereas, at a concentration of $0 / 02 \mathrm{mg} / \mathrm{mL}$, approximately $70 \%$ of the worms hatched. Within 6 hours, from $3.125 \mathrm{mg} / \mathrm{mL}$ to high, all worms died. ${ }^{23}$ A study used the methanolic and aqueous extract of Prunella vulgaris to examine its anthelmintic properties against Haemonchus contortus. In this study, crude methanolic extract with LC50 (Lethal concentration of 50) equivalent to $2.48 \mathrm{mg} / \mathrm{mL}$ was used which showed more inhibitory effects on EHT than a crude aqueous extract with LC50 equal to $3.36 \mathrm{mg} / \mathrm{mL}$. Also, the group treated with methanolic extract of Prunella vulgaris had the highest decrease in the number of eggs in the feces. ${ }^{24}$ Brunet et al. studied the role of Onobrychis viciifolia (Sainfoin) extract in larva stage B L3 of Haemonchus contortus worm using morphological changes. Larval envelope structure at a concentration of $1200 \mathrm{mg} / \mathrm{mL}$ of Sainfoin extract using a Transmission Electron Microscope (TEM) shows changes such as muscle cell breakdown, intestinal cells breakdown, hypodermic changes, abnormal chromatin density of the nucleus of epithelial cells, and wounds and lesions created on the surface of the worm. ${ }^{25}$

\section{The use of herbs for Cooperia punctate}

This parasite is 5-9 $\mathrm{mm}$ long. In all species of this parasite, the head part is dilated and has transverse lines. Thick spicules, often with a wing-like dilation, are in the midline. The female parasite has a long tail, and its genital area is covered. The parasite lives in the small intestine of cows. ${ }^{26}$ Von Son-de Fernex et al. Using the isolated component of Gliricidia sepium against Cooperia punctata worms showed that this extract inhibits the growth and egg hatching of Cooperia punctata worm (Half maximal effective concentration or EC50 equivalent to $0.0240 .082 \mathrm{mg} / \mathrm{mL}$ ). Examining worm eggs with SEM and TEM revealed changes and fractures in parasite eggshell through treatment with $\mathrm{H}$-chromene-2-one 2 component. ${ }^{27}$ Also, the use of components derived from the aqueous extract of Leucaena leucocephala to conduct EHT and worm egg damages showed that the percentage of egg hatching inhibition in the $\mathrm{LlC1F} 3$ segment is equal to $90 / 49 \pm 2 / 85$, which was higher than other components. Also, studying parasite eggs after treatment with LIC1F3 Fraction using SEM revealed the eggshell's disintegration and a formation of depressions and tears on the eggs' surface. Also, changes in electron density and thickening of the layer of worm eggs were observed by TEM. ${ }^{28}$

\section{The use of herbs for Toxocara canis}

Toxocara canis is a nematode that causes Toxocariasis disease in humans, which is caused by infection formed after consumption of Toxocara canis eggs in soils contaminated with dog feces. Children are more susceptible to this infection due to gluttony (Pica). ${ }^{4,29}$ In a study, antiparasitic effects of Pycnantha angolensis, Chenopodium ambrosioides, and Nutridesintox extracts against
Toxocara canis larva were evaluated. The results showed that the hexane extract of Chenopodium ambrosioides is more effective than other extracts in vivo environment and reduces inflammatory reactions caused by Toxocara Canis larva infection. ${ }^{30}$

\section{The use of herbs for Ancylostoma caninum}

Ancylostoma caninum is a hookworm that mainly causes diseases in dogs' small intestine. This worm infection shows a wide range of symptoms in dogs. Other hosts include carnivores such as wolves, foxes, and cats, and also a small number of diseases have been reported in humans. ${ }^{31}$ In a study by Monteiro et al., the role of ethanolic extract and essential oil of Chenopodium ambrosioides $L$ in controlling Ancylostoma caninum worms is discussed. ${ }^{30}$ Chenopodium ambrosioides essential oil was effective in a concentration of $140 \mu \mathrm{L} / \mathrm{mL}$ against larva $\mathrm{L} 3$ and reduces the number of eggs per each gram of feces the aim of this study was quantitate the yield the chemical composition of the essential oil of C. ambrosioides and they found that as well as the in vitro effect of the ethanolic extract and the essential oil in L3 of Ancylostoma spp and the in vivo effect(s) of the essential oil in dogs. The effects of the ethanol extract and essential oil on Ancylostoma spp were observed in vitro by exposing larvae to the extract at concentrations ranging from $0.005 \mathrm{~g} \mathrm{~mL}-1$ to $0.2 \mathrm{~g} \mathrm{~mL}-1$ and to essential oil at concentrations of $50,100,150 \mu \mathrm{L} \mathrm{mL}-1 .{ }^{32}$

\section{The use of herbs for Trichostrongylus spp}

Trichostrongylus spp is a species of nematodes distributed among herbivorous animals worldwide. At least 10 species of Trichostrongylus are associated with human infections. The infection occurs through consuming infectious larvae in vegetables and contaminated water. ${ }^{33}$ Today, anthelmintic resistance is expanding worldwide; therefore, manufacturing non-synthetic drugs seems necessary. ${ }^{34}$ Kozan et al. investigated the anthelmintic role of Vicia Pannonica against Trichostrongylus parasites. In this study, aqueous, ethanoic, chloroformed, Estonian, and hexane extracts of Vicia pannonica var. purpurascens had a $100 \%$ effect on larval movements in $10^{\text {th }}$ minute and all mentioned extracts damaged the larval sheath in this study they cover in vivo and in vitro tests that have been developed for the detection of nematode resistant to the main anthelmintic groups, but each suffer to some degree from reliability reproducibility, sensitivity and ease of interpretation. ${ }^{35}$ Aqueous extracts of Pithecellobium dulce and Lysiloma acapulcensis had lethal effects on Trichostrongylus clubriformis eggs at concentrations of 250 and $500 \mu \mathrm{g} / \mathrm{mL}$. Also, Pithecellobium dulce has lower larvacidal effects than aqueous extracts of Lysiloma acapulcensis and Levamisole. ${ }^{36}$

\section{The use of herbs for Angiostrongylus}

Angiostrongylus is a nematode parasite that can cause diseases in humans' gastrointestinal tract and central nervous system. Angiostrongylus cantonensis, called rat lungworm, causes eosinophilic meningitis disease commonly found in Southern East Asia and the Pacific Islands. ${ }^{37}$ In one study, the effects of TSII-A (Tanshinone IIA) and Cryptotanshinone (CPT) with Albendazole on ocular nerve inflammation caused by Angiostrongylus cantonensis infection were evaluated in mice. The results showed the suitability of Albendazole in combination with TSI-E in the treatment of the optic nerve inflammation caused by Angiostrongylus cantonensis. ${ }^{38}$

\section{The use of herbs for Onchocerca ochengi}

Onchocerca ochengi is a bovine Filariasis parasite found in 
West Africa as Cameroon. It is closely related to a human parasite called Onchocerca volvulus. ${ }^{39}$ Studies by Ndjonka et al. showed antiparasitic activities of aqueous extracts of Annona senegalensis and Euphorbia hirtam and ethanolic extracts of Parquetina nigrescens, Khaya senegalensis, and Anogeissus leiocarpus with an LC50 concentration in a range of $0.08-0.55 \mathrm{mg} / \mathrm{mL}$ for Onchocerca ochengi worm. Based on this study, Euphorbia hirta, Annona senegalensis, Khaya senegalensis, and Anogeissus leiocarpus extracts can be suitable alternatives for worm infections. ${ }^{40}$

\section{The use of herbs for Ascaridia galli}

Ascaridia galli is one of the Ascaridia genus nematodes that live in poultry intestines and sometimes causes accidental closure of the intestine and Ascariasis in poultry. ${ }^{41}$ In a study by Bazh and El-Bahy, a concentration of $100 \mathrm{mg} / \mathrm{mL}$ of ginger (zingiber officinale) and turmeric (curcuma longa) in 48 hours in an in vitro environment causes the death of Ascaridia galli worms in an in vivo environment, there was lower mortality. Also, in all concentrations, ginger caused more mortality than turmeric. ${ }^{11}$

\section{Herbs' anthelmintic effect for Toxocara vitulorum}

Toxocara vitulorum is the largest parasite, and its female species are up to $30 \mathrm{~cm}$ long. This parasite that lives in the intestine of cattle and buffalo calves, its spread is currently global, and often comes from tropical and subtropical areas, is one of the most important parasites of newborn calves. ${ }^{42}$ In one study, using the methanolic extract of Balanites aegyptiaca fruit at a concentration of $240 \mathrm{mg} / \mathrm{mL}$ showed $100 \%$ inhibitory activity on Toxocara vitulorum egg growth. ${ }^{43}$

\section{The use of herbs in Trichinella spiralis}

An adult Trichinella spiralis is 4-6 cm long with a thick posterior end. Its anterior end suddenly narrows and forms as a thin and long wire embedded in the mucosa. Trichinella spiralis is the most important cause of human infections. ${ }^{44}$ A study by Shalaby et al. showed that within five days, the methanolic extract of Balanites aegyptiaca with a concentration of $1000 \mathrm{mg} / \mathrm{mL}$ per $\mathrm{kg}$ of body weight in Rat reduced migration and death of larvae for $61 / 7 \%$ and, $81 / 7 \%$ respectively. ${ }^{45}$

\section{The use of herbs for Hymenolepis diminuta}

Hymenolepis diminuta that is also known as Tap worm rat (Rat), is the cause of Hymenolepiasis. Unlike Hymenolepis nana, this worm uses insects as mediator hosts for transmitting to infect humans. ${ }^{46}$ Also, in a study by Yadav and Nath, the Cynodon dactylon extract had anthelmintic properties. A concentration of 40 $\mathrm{mg} / \mathrm{mL}$ of the Cynodon dactylon extract caused paralysis and death of worms at hours $4 / 12 \pm 0 / 55$ and $5.16 \pm 0.32$, respectively. Also, the treatment of rats by a dose of $800 \mathrm{mg} / \mathrm{mL} / \mathrm{kg}$ for five days caused a reduction of $77.64 \%$ and $79.00 \%$ in the number of eggs per gram of feces and the worm load, respectively, after the treatment with Cynodon dactylon. ${ }^{47}$

\section{The use of herbs for worms of the Fasciolidae family}

These worms are large leaf-shaped flukes. The cone-shaped anterior end and the anterior balloon are located at the end of the cone. The abdomen balloon is at the level of the so-called shoulders of the fluke. There are three main genera, including Fasciola, Fascioloides, and Fasciolopsis, in this family that often cause severe damage to their host's liver and intestines. ${ }^{48}$ The ethanolic extract of Alpinia nigra in a $20 \mathrm{mg} / \mathrm{mL}$ concentration at hour $2.14 \pm 0.48$ caused worm paralysis; While at hour $3.94 \pm 0.23$ caused the death of Fasciolopsis buski worms. In the control group, worms' physical activities continued until hour $21.05 \pm 0.22 .{ }^{49}$ A study on Fasciola hepatica worm showed that the extract of Lantana camara, Cajanus cajan, and Piper auritum at a $50 \mathrm{mg} / \mathrm{mL}$ concentration caused $100 \%$ death worms. Whereas extracts of Bocconia frutescens and Artemisia Mexicana plants at a $125 \mathrm{mg} / \mathrm{mL}$ concentration caused $100 \%$ death of worms. ${ }^{50}$ Research by Roy and Swargiary discussed about the role of Fasciolopsis buski in changing enzymes at Alpinia nigra tegument. Accordingly, by the effect of Alpinia nigra extract, the overall activity of Acid phosphatase (ATPase), Adenosine triphosphatase (ATPase), and Alkaline phosphatase (AlkPase) enzymes decreased because these enzymes have an important role in parasite survival by digesting and absorbing the nutrients. ${ }^{51}$ Using Soybean extract reduces liver lesions because of the presence of Fasciola gigantica and the amount of 3-cell caspase of the liver, and on the other hand, caused induced apoptosis in the parasite DNA. ${ }^{52}$

\section{The use of herbs for the Schistosomatidae family's}

This family is located in the gastrointestinal tract and bladder's blood vessels. Schistosomiasis is an acute and chronic disease caused by blood trematodes of the genus Schistosoma. About 206 million people need preventive treatments to reduce the infection and prevent death from schistosomiasis. ${ }^{53}$ In one study, different concentrations of Allicin caused morphological changes in Schistosoma mansoni in a way that a concentration of $10 \mathrm{mg} / \mathrm{mL}$ led to changes in small bumps and a reduction in the surface of the worm and at higher concentrations increased damaging the tegument, including vesicles and ulcers. ${ }^{54} \mathrm{~A}$ study by Matos-Rocha et al. discussed the role of Mentha x villosa Huds Essential Oil (MVEO) against Schistosoma mansoni worms. MVEO at a concentration of $500 \mu \mathrm{g} / \mathrm{mL}$ caused the death of all worms within 24 hours, and examining it by SEM showed bubble-like lesions formed around the body of the worm and erosion in small bumps in some areas of the abdomen. Also, by studying using TEM, changes were observed in integument and vesiculation in the syncytial matrix region. ${ }^{55}$ Using the Clerodendrum umbellatum extract in mice infected by Schistosoma mansoni significantly reduced the number of eggs excreted from mice; In a way that the amount of excreted eggs in treated mice with a concentration of 80 $\mathrm{mg} / \mathrm{kg}$ and $160 \mathrm{mg} / \mathrm{kg}$ decreased by a rate of $75.48 \%$ and $85.14 \%$, respectively. ${ }^{56}$

\section{Herbs' use for the Paramphistomatidae family's}

The adult Paramphistomum worm often exists in the ruminant pre-stomachs. Although, there is a species found in the intestines of ruminants, pigs, and dogs, which sometimes causes intestinal inflammation with edema, bleeding, and wounds. ${ }^{57}$ In one study, the methanolic extract of Bombax malabaricus at a concentration of $100 \mathrm{mg} / \mathrm{mL}$ at minutes $22.17 \pm 0.48$ caused the death of Paramphistomum explanandum worms, and at minutes $18.50 \pm 0.62$ caused worm paralysis. ${ }^{58}$ The Balanites aegyptiaca (BAE) fruit extract at a $200 \mu \mathrm{g} / \mathrm{mL}$ concentration caused severe damage to the Paramphistomum microbothrium tegument and the deformation of both suckers of the worm. ${ }^{59}$

\section{Conclusions}

Nearly all the plants in this review showed promising anthelmintic effects, mainly in vitro studies also plant medicines are thought to be good sources for the development of effective 
anthelmintic agents. This work as well mentioned that there is a lack of studies on the effect of chemical constituents isolated from plants against helminth infections. Therefore, it is necessary to look for further effective anthelmintic drugs with minimum side effects.

\section{References}

1. Daumerie D, Savioli L. Working to overcome the global impact of neglected tropical diseases: first WHO report on neglected tropical diseases, vol. 1. Geneva: World Health Organization, 2010.

2. Perry BD. Investing in animal health research to alleviate poverty. ILRI (aka ILCA and ILRAD), 2002.

3. Bull K, Cook A, Hopper NA, et al. Effects of the novel anthelmintic emodepside on the locomotion, egg-laying behaviour and development of Caenorhabditis elegans. Int J Parasitol 2007;37:627-36.

4. Cheraghipour K, Moridnia A, Sharifi M, et al. The effect of medicinal plant extracts on helminthes: A systematic review. $\mathrm{J}$ Isfahan Med Sch 2019;37:462-74.

5. Satyavati GV. Use of plant drugs in Indian traditional systems of medicine an their relevance to primary health care. New Delhi, India: Indian Council of Medical Reserch; 1985.

6. Liu LX, Weller PF. An update on antiparasitic drugs. N Engl J Med 1996;334:1178-84.

7. Qi Z. WHO Traditional Medicine Strategy. 2014-2023. Geneva: World Health Organisation; 2013.

8. Deori K, Yadav AK. Anthelmintic effects of Oroxylum indicum stem bark extract on juvenile and adult stages of Hymenolepis diminuta (Cestoda), an in vitro and in vivo study. Parasitol Res 2016;115:1275-85.

9. Keiser PB, Nutman TB. Strongyloides stercoralis in the immunocompromised population. Clin Microbiol Rev 2004;17;208-17.

10. Bhardwaj LK, Anand L, Chandrul KK, Patil KS. In-vitro anthelmintic activity of Ficus benghalensis Linn leaves extracts. Asian J Pharm Clin Res, 2012;5:118-20.

11. Bazh EKA, El-Bahy NM. In vitro and in vivo screening of anthelmintic activity of ginger and curcumin on Ascaridia galli. Parasitol Res 2013;112:3679-86.

12. Roy B. Anthelmintic activity of Artemisia maritima against Artyfechinostomum sufrartyfex, a zoonotic parasite in northeast India. Riv Parassitol 2003;64:143-8.

13. Faridnia R, Kalani H, Fakhar M, Akhtari J. Investigating in vitro anti-leishmanial effects of silibinin and silymarin on Leishmania major. Ann Parasitol 2018;64:29-35.

14. Eskandarian AA, Jafari H, Asghari G, et al. In vitro antileishmanial activity of Falcaria vulgaris fractions on Leishmania major. Jundishapur J Nat Pharm Prod 2017;12:e63754.

15. Mirzaei F, Bafghi AF, Mohaghegh MA, et al. In vitro antileishmanial activity of Satureja hortensis and Artemisia dracunculus extracts on Leishmania major promastigotes. J Parasit Dis 2016;40:1571-4.

16. Machen RV, Craddock F, Craig T, Fuchs TW. A Haemonchus contortus management plan for sheep and goats in Texas. Texas FARMER Collect 1998.

17. Sambodo P, Prastowo J, Kurniasih K, Indarjulianto S. In vitro potential anthelmintic activity of Biophytum petersianum on Haemonchus contortus. Vet World 2018;11:1.

18. von Son-de Fernex E, Alonso-Díaz MA, Valles-de la Mora B, Capetillo-Leal CM. In vitro anthelmintic activity of five trop- ical legumes on the exsheathment and motility of Haemonchus contortus infective larvae. Exp Parasitol 2012;131:413-8.

19. Ferreira LE, Castro PMN, Chagas ACS, et al. In vitro anthelmintic activity of aqueous leaf extract of Annona muricata L.(Annonaceae) against Haemonchus contortus from sheep. Exp Parasitol 2013;134:327-32.

20. Castañeda-Ramírez GS, Mathieu C, Vilarem G, et al. Age of Haemonchus contortus third stage infective larvae is a factor influencing the in vitro assessment of anthelmintic properties of tannin containing plant extracts. Vet Parasitol 2017;243:130-4.

21. Carvalho CO, Chagas AC, Cotinguiba F, et al. The anthelmintic effect of plant extracts on Haemonchus contortus and Strongyloides venezuelensis. Vet Parasitol 2012;183:2608.

22. Eguale T, Tadesse D, Giday M. In vitro anthelmintic activity of crude extracts of five medicinal plants against egg-hatching and larval development of Haemonchus contortus. J Ethnopharmacol 2011;137:108-13.

23. Zaman MA, Iqbal Z, Khan MN, Muhammad G. Anthelmintic activity of a herbal formulation against gastrointestinal nematodes of sheep. Pak Vet J 2012;32:117-21.

24. Lone BA, Chishti MZ, Bhat FA, et al. Anthelmintic activities of aqueous and methanol extracts of Prunella vulgaris L. Nat Prod Chem Res 2017;5:2.

25. Brunet S, Fourquaux I, Hoste H. Ultrastructural changes in the third-stage, infective larvae of ruminant nematodes treated with sainfoin (Onobrychis viciifolia) extract. Parasitol Int 2011;60: 419-24.

26. Stromberg BE, et al. Cooperia punctata: effect on cattle productivity? Vet Parasitol 2012;183:284-91.

27. von Son-de Fernex E, Alonso-Díaz MÁ, Valles-de la Mora B, et al. Anthelmintic effect of $2 \mathrm{H}$-chromen-2-one isolated from Gliricidia sepium against Cooperia punctate. Exp Parasitol 2017;178:1-6.

28. von Son-de Fernex E, Alonso-Díaz MÁ, Mendoza-de Gives P, Valles-de la Mora B, et al. Elucidation of Leucaena leucocephala anthelmintic-like phytochemicals and the ultrastructural damage generated to eggs of Cooperia spp. Vet Parasitol 2015;214:89-95.

29. Despommier D. Toxocariasis: clinical aspects, epidemiology, medical ecology, and molecular aspects. Clin Microbiol Rev 2003;16:265-72.

30. Reis M, Trinca A, Ferreira MJU, Monsalve-Puello AR, Grácio MAA. Toxocara canis: potential activity of natural products against second-stage larvae in vitro and in vivo. Exp Parasitol 2010;126:191-7.

31. Ng-Nguyen D, Hii SF, Nguyen VAT, et al. Re-evaluation of the species of hookworms infecting dogs in Central Vietnam. Parasit Vectors 2015;8:1-6.

32. Monteiro JNM, Archanjo AB, Passos GP, et al. Chenopodium ambrosioides L. essential oil and ethanol extract on control of canine Ancylostoma spp. Semin Ciências Agrárias 2017;38:1947-54.

33. Gibbs HC. Epidemiology, diagnosis and control of gastrointestinal parasitism. Kenya, Ilard 1986;121.

34. Taylor MA, Hunt KR, Goodyear KL. Anthelmintic resistance detection methods. Vet Parasitol 2002;103:183-94.

35. Kozan E, Anul SA, Tatli II. In vitro anthelmintic effect of Vicia pannonica var. purpurascens on trichostrongylosis in sheep. Exp Parasitol 2013;134:299-303.

36. Olmedo-Juárez A, Rojo-Rubio R, Arece-García J, et al. In 
vitro activity of Pithecellobium dulce and Lysiloma acapulcensis on exogenous development stages of sheep gastrointestinal strongyles. Ital J Anim Sci 2014;13:3104.

37. Thiengo SC, de Oliveira Simões R, Fernandez MA, Júnior AM. Angiostrongylus cantonensis and rat lungworm disease in Brazil. Hawai'i J Med Public Heal 2013;72:18.

38. Feng F, Feng Y, Liu Z, et al. Effects of Albendazole combined with TSII-A (a Chinese herb compound) on optic neuritis caused by Angiostrongylus cantonensis in BALB/c mice. Parasit Vectors 2015;8:1-8.

39. Doyle SR, Armoo S, Renz A, et al. Discrimination between Onchocerca volvulus and O. ochengi filarial larvae in Simulium damnosum (sl.) and their distribution throughout central Ghana using a versatile high-resolution speciation assay. Parasit Vectors 2016;9:536.

40. Ndjonka D, Agyare C, Lüersen K, et al. In vitro activity of Cameroonian and Ghanaian medicinal plants on parasitic (Onchocerca ochengi) and free-living (Caenorhabditis elegans) nematodes. J Helminthol 2011;85:304-12.

41. Lalchhandama K. On the structure of Ascaridia galli, the roundworm of domestic fowl. Sci Vis 2010;10:20-30.

42. Ahmed R, Wani ZA, Allaie IM, et al. Toxocara vitulorum in a suckling calf: a case study. J Parasit Dis 2016;40:1330-1.

43. Shalaby HA, El Namaky AH, Khalil FA, Kandil OM. Efficacy of methanolic extract of Balanites aegyptiaca fruits on Toxocara vitulorum. Vet Parasitol 2012;183:86-392.

44. Mitreva M, Jasmer DP. Biology and genome of Trichinella spiralis. 2006. In: WormBook: The Online Review of C. elegans Biology [Internet]. Pasadena (CA): WormBook; 20052018.

45. Shalaby MA, Moghazy FM, Shalaby HA, Nasr SM. Effect of methanolic extract of Balanites aegyptiaca fruits on enteral and parenteral stages of Trichinella spiralis in rats. Parasitol Res 2010;107:17-25.

46. Sheiman IM, Shkutin MF, Terenina NB, Gustafsson MKS. A behavioral study of the beetle Tenebrio molitor infected with cysticercoids of the rat tapeworm Hymenolepis diminuta. Naturwissenschaften 2006;93:305-8.

47. Yadav AK, Nath P. Anthelmintic effects and toxicity of Cynodon dactylon (L.) Pers. in rodent models. J Complement Med Res 2017;6:407-13.

48. Olson PD, Cribb TH, Tkach VV, et al. Phylogeny and classification of the Digenea (Platyhelminthes: Trematoda). Int J Parasitol 2003;33:733-55.

49. Swargiary A, Roy B. In vitro anthelmintic efficacy of Alpinia nigra and its bioactive compound, astragalin against Fasciolopsis buski. Int J Pharm Pharm Sci 2015;7:30-35.

50. Alvarez-Mercado JM, Ibarra-Velarde F, Alonso-Díaz MÁ, et al. In vitro antihelmintic effect of fifteen tropical plant extracts on excysted flukes of Fasciola hepatica. BMC Vet Res 2015;11:45.

51. Roy B, Swargiary A. Anthelmintic efficacy of ethanolic shoot extract of Alpinia nigra on tegumental enzymes of Fasciolopsis buski, a giant intestinal parasite. J Parasit Dis 2009;33:48-53.

52. Nassef NE, El-Kersh WM, El Sobky MM, et al. In-vitro and in-vivo Assessment of the Effect of Soybean Extract on Fasciola gigantica Infection in Comparison with Triclabendazole. Menoufia Med J. 2014;27:93.

53. Savioli L, Albonico M, Daumerie D, et al. Review of the 2017 WHO Guideline: Preventive chemotherapy to control soiltransmitted helminth infections in at-risk population groups. An opportunity lost in translation. PLoS Negl Trop Dis 2018;12:e006296.

54. Lima CM, Freitas FI, Morais LC, et al. Ultrastructural study on the morphological changes to male worms of Schistosoma mansoni after in vitro exposure to allicin. Rev Soc Bras Med Trop 2011;44:327-30.

55. Matos-Rocha TJ, Cavalcanti MG, Veras DL, et al. Ultrastructural changes in Schistosoma mansoni male worms after in vitro incubation with the essential oil of Mentha $\mathrm{x}$ villosa Huds. Rev Inst Med Trop Sao Paulo 2016;58:4.

56. Jatsa HB, Sock TM, Tchuente LA, Kamtchouing P. Evaluation of the in vivo activity of different concentrations of Clerodendrum umbellatum Poir against Schistosoma mansoni infection in mice. Afr $\mathrm{J}$ Tradit Complement Altern Med 2009;6:216-21.

57. Hossain E, Chandra G, Nandy AP, et al. Anthelmintic effect of a methanol extract of leaves of Dregea volubilis on Paramphistomum explanatum. Parasitol Res 2012;110:80914.

58. Hossain E, Chandra G, Nandy AP, et al. Anthelmintic effect of a methanol extract of Bombax malabaricum leaves on Paramphistomum explanatum. Parasitol Res 2012;110:1097102.

59. Shalaby H, Soad N, Farag T. Tegumental effects of methanolic extract of Balanites aegyptiaca fruits on adult Paramphistomum microbothrium (Fischoeder 1901) under laboratory conditions. Iran J Parasitol 2016;11:396.

60. Dixit AK, Das G, Dixit P, Sharma RL. Efficacy of herbal extracts and closantel against fenbendazole-resistant Haemonchus contortus. J Helminthol 2019;93:529-32.

61. Basha $\mathrm{H}$, et al. In-vitro anthelmintic efficacy of the $80 \%$ hydro-alcohol extract of Myrsine africana (kechemo) leaf on hookworm larvae. J Public Heal Dis Prev 2018;1:106.

62. Alowanou GG, Azando EVBB, Adenilé AD, et al. Evaluation of the in vivo anthelmintic properties of Mitragyna inermis (Willd.) as a livestock dewormer against parasitic hematophagous worm Haemonchus contortus infections in different breeds of lambs. Trop Anim Health Prod 2020;52:309-19.

63. Joshi UP, Wagh RD, Prabhakar Joshi U, Dayaram Wagh R. In vitro anthelmintic activity of Maytenus Emarginata stem bark on indian adult earthworm. In Vitro 2019;12:3.

64. Tavassoli M, Jalilzadeh-Amin G, Fard VRB, Esfandiarpour R. The in vitro effect of Ferula asafoetida and Allium sativum extracts on Strongylus spp. Ann Parasitol 2018;64:59-63.

65. Muunda M, Musubire JB, Nassali G, et al. Combined effects of Carica papaya seeds with Albendazole on adult pheritima posthuma. East Africa Sci 2020;2:88-91.

66. Belemlilga MB, Traoré A, Belemnaba L, et al. Ovicidal and larvicidal activities of Saba senegalensis (A. DC) Pichon (Apocynaceae) extracts and fractions on heligmosomoides bakeri (Nematoda, Heligmosomatidae). J Pharm Res Int 2019;31:1-13.

67. Widiarso BP, Kurniasih K, Prastowo J, Nurcahyo W. Morphology and morphometry of Haemonchus contortus exposed to Gigantochloa apus crude aqueous extract. Vet World 2018;11:921-5.

68. Da Rocha LO, et al. Chemical characterization and in vitro biological activity of Cymbopogon citratus extracts against Haemonchus spp. and Trichostrongylus spp. nematodes from sheep. Parasitology 2020;147:1559-68.

69. Maestrini M, Tava A, Mancini S, et al. In vitro anthelmintic activity of Saponins from Medicago spp. against sheep gastrointestinal nematodes. Molecules 2020;25:242. 
70. Houshmand E, Kamalifar HS, Elmi H. In vitro scolicidal effect of ginger (Zingiber officinale Roscoe) ethanolic extract against protoscolices of hydatid cyst. Iran J Vet Med 2019;13:87-99.

71. Goswami S, Singh RP. In vitro assessment of anthelmintic and alpha-amylase inhibition of schleichera oleosa (Lour.) oken leaf extracts. Asian J Pharm Clin Res 2018;11:487-91.

72. Mubarokah WW, Nurcahyo W, Prastowo J, Kurniasih K. In vitro and in vivo Areca catechu crude aqueous extract as an anthelmintic against Ascaridia galli infection in chickens. Vet World 2019;12:877.

73. Shalaby H, El Namaky A, Kandil O, Hassan N. In vitro assessment of Balanites aegyptiaca fruit methanolic extract on the adult Toxocara canis. Iran J Parasitol 2018;13:643.

74. Tsehayneh B, Melaku A. In vitro egg hatchability inhibition effect of Albizia gummifera, Phytolacca dodecandra, and Vernonia amygdalina against natural infection of ovine GIT nematodes. J Med Bot 2019;3:5-7.

75. Wahyuni S, Sunarso S, Prasetiyono BWHE, Satrija F. Exploration of anthelmintic activity of Cassia spp. extracts on gastrointestinal nematodes of sheep. J Adv Vet Anim Res 2019;6:236-40.

76. Zaheer S, Hussain A, Khalil A, et al. In vitro anthelmintic activity of ethanolic extracts of Camellia sinensis L. and Albizia lebbeck L. against Haemonchus contortus. Punjab Univ J Zool 2019;34:41-45.

77. Alowanou GG, Olounladé PA, Akouèdegni GC, et al. In vitro anthelmintic effects of Bridelia ferruginea, Combretum glutinosum, and Mitragyna inermis leaf extracts on Haemonchus contortus, an abomasal nematode of small ruminants. Parasitol Res 2019;118:1215-23.

78. Hmoodal-Khalidy K. Molecular diagnosis of hymenolepisnanain experimentally infected swiss mice and study the effect of the hot aqueous extract of syzygiumaromaticum (clove) on the worms. J Res Lepid 2020;51:147-57.

79. Giradkar PN, Lkhande VK. Worm Infestation and child health care: anthelmintic pellets of papaya. J Pharmaceut Adv Res 2018;1:101-10.

80. Philip R, Krishnasamy K, Abraham E. Evaluation of in vitro anthelmintic activity of extracts of jasminum sessiliflorum. Int J Res Pharm Sci 2019;10:2542-44.

81. Kharisma VL, Koesdarto S, Supriandono K, et al. Anthelmintic activity ethanol extract of Ocimum sanctum Linn leaves against Ascaridia galli in vitro. J Parasite Sci 2018;2:21-8.

82. Lalruatfela B, Lalthanpuii PB, Lalnunfela C, Lalchhandama K. Nematocidal effects of tobacco infusion (tuibur) against intestinal helminth parasites of chicken. J Environ Biol 2020;41:840-4.

83. Freitas Macedo IT, Beserra de Oliveira LM, Pinheiro André WP, et al. Anthelmintic effect of Cymbopogon citratus essential oil and its nanoemulsion on sheep gastrointestinal nematodes Efeito anti-helmíntico do óleo essencial de Cymbopogon citratus e sua nanoemulsão sobre nematoides gastrintestinais de ovinos. Electron Braz J Vet Parasitol 2019;28:522-7.

84. D'Ambola $\mathrm{M}$, et al. In vitro anthelminthic efficacy of Hypoestes forskaolii (Vahl) R. Br (Acanthaceae) extracts on gastrointestinal nematodes of sheep. Vet Sci 2018;5:89.

85. Cabral ERM, Moraes D, Levenhagen MA, et al. In vitro ovicidal and larvicidal activity of Carica papaya seed hexane extract against Strongyloides venezuelensis. Rev Inst Med Trop Sao Paulo 2019;61:
86. Ahmed AH, Ejo M, Feyera T, et al. In vitro anthelmintic activity of crude extracts of Artemisia herba-alba and Punica granatum against Haemonchus contortus. J Parasitol Res 2020;2020: 4950196.

87. Ngwewondo A, et al. Filaricidal properties of Lantana camara and Tamarindus indica extracts, and Lantadene A from L. camara against Onchocerca ochengi and Loa loa. PLoS Negl Trop Dis 2018;12:e006565.

88. Olukotun AB, Bello IA, Oyewale OA. Phytochemical and anthelmintic activity of Terminalia catappa (Linn) leaves. J Appl Sci Environ Manag 2018;22:1343.

89. Nath S, Pal S, Sanyal PK, et al. Anthelmintic activity of curcuma longa ethanolic extract against benzimidazole resistant gastrointestinal nematodes in goats. Int $\mathrm{J}$ Livestock Res 2019;9:117-22.

90. Hamad KK. Assessment of Azadirachta indica seed kernel extracts to restrict the rampancy of antinematicidal-resistant Haemonchus contortus in ovine. Zanco J Pure Appl Sci 2018;30:29-43.

91. Aderibigbe SA, Idowu SO. Anthelmintic activity of Ocimum gratissimum and Cymbopogon citratus leaf extracts against Haemonchus placei adult worm. J Pharm Bioresour 2020;17:8-12.

92. Mahmoudvand H, Pakravanan M, Aflatoonian MR, et al. Efficacy and safety of Curcuma longa essential oil to inactivate hydatid cyst protoscoleces. BMC Complement Altern Med 2019;19:187.

93. Behera DR, Bhatnagar S. Assessment of macrofilaricidal activity of leaf extracts of Terminalia sp. against bovine filarial parasite Setaria cervi. J Infect Public Health 2018;11:6437.

94. Sujith S, Priya MN, Deepa CK, Usha PTA. Characterization of the Anthelmintic Activity of Murraya koenigii (Linn.). Pharmacogn J 2018;10:s100-3.

95. Zangueu CB, Olounlade AP, Ossokomack M, et al. In vitro effects of aqueous extract from Maytenus senegalensis (Lam.) Exell stem bark on egg hatching, larval migration and adult worms of Haemonchus contortus. BMC Vet Res 2018;14:147.

96. Zaman MA, Qamar W, Yousaf S, et al. In vitro Experiments Revealed the Anthelmintic Potential of Herbal Complex against Haemonchus contortus. Pakistan Vet J 2019:128.

97. Chitura T, Shiba MR, Afful DB, et al. In vitro anthelmintic activity of seven medicinal plants used to control livestock internal parasites in chief Albert Luthuli municipality, South Africa. Livestock Res Rural Dev 2019;31:14.

98. Chaudhari MK, Chaudhari RD, Girase PR, et al. Anthelmentic activity of Tridax procumbens Linn leaves on indian earthworms. Res J Pharm Technol 2018;11:5373-5.

99. Tessema EN, Neubert RHH, Tanemossu SAF, et al. Anthelmintic activity-guided fractionation and GC-MS analysis of extracts from Embelia schimperi fruits. In J Appl Res Nat Products 2018. Available from: https://www.researchgate.net/ publication/325287233_Anthelmintic_activity-guided_fractionation_and_GC-MS_analysis_of_extracts_from Embelia_schimperi_fruits

100. Naraparaju NA, Lokesh C, Sojan WA, et al. Phytochemical examination of plant and preforming anthelmintic activity of ethanolic extract of dioscorea mexicana fruits on pherithima posthuma and bioassy on frog rectum abdominal muscle. Int $\mathrm{J}$ Res Eng Sci Manag 2018;1:53-4.

101. Mallya R, Malim F, Naik A, Bhitre M. Evaluation of Anthelmintic Potential of Leaves and Fruits of Zanthoxylum rhetsa. Pharmacogn J 2019;11:475-8. 
102. Sen D, Agnihotri RK, Sharma D, Moudgil AD. In-Vitro Assays on Mangifera indica and Embelia ribes against Ascaridia galli of poultry. Himachal J Agric Res 2018;44:11724.

103. Aderibigbe SA, Oyeniran OS, Idowu SO. Anthelmintic activity of Nauclea diderrichii leaf extracts and fractions against adult haemonchus placei. Niger J Pharm. Res 2020;16:81-6.

104. Singh $\mathrm{G}$, et al. Investigation of in vitro anthelmintic activity of Caesalpinia pulcherrima leaves. Plant Arch 2019;19:4527-30.

105. Jadhav A, Patil S, Inamdar S. A study on in vitro anthelmintic activity of ethanolic extracts of leaves Citrus aurantifolia swingle against Pheritima posthuma. Int J Pharm Sci Med
2018;3:1-8.

106. Islam R, Zahra SFT, Sumon SMI, et al. Evaluation of anthelmintic activity of ethanolic extracts of Carica papaya leaves using Paramphistomum cervi and Haemonchus contortus. African J Pharm Pharmacol 2019;13:146-50.

107. Barone CD, et al. Anthelmintic efficacy of cranberry vine extracts on ovine Haemonchus contortus. Vet Parasitol 2018;253:122-9.

108. Lalchhandama K. Anthelmintic activity of millettia pachycarpa root bark extract on an intestinal roundworm, Ascaridia galli. Pharmacogn J 2019;11:1428-33. 